Палкина Ю.А. ${ }^{1}$, Кривец Т.П. ${ }^{1}$

${ }^{1}$ Дальневосточный федеральный университет, г. Владивосток

\title{
Преступления в экономической сфере: ответственность бухгалтера
}

\begin{abstract}
АННОТАЦИЯ:
Статья раскрывает особенности преступлений в экономической сфере на примере преступлений бухгалтера на предприятии. Автором выделены основные причины бухгалтерских преступлений, рассмотрена классификация основных преступлений и обозначены наказания за их совершение на основе статей Налогового Кодекса. Кроме того, автором были предложены способы предотвращения преступлений бухгалтера на предприятии.
\end{abstract}

КЛЮЧЕВЫЕ СЛОВА: бухгалтер, риски, ответственность, субъект и объект преступления, махинации, наказание

JEL: K14, K34, K42, M41

ДЛЯ ЦИТИРОВАНИЯ:

Палкина Ю.А., Кривец Т.П. Преступления в экономической сфере: ответственность бухгалтера // Экономика, предпринимательство и право. - 2014. - Т. 4. - № 25. - с. 916. - http://journals.creativeconomy.ru/index.php/epp/article/view/301/

Палкина Юлия Александровна, студентка Дальневосточного федерального университета, г. Владивосток (ulia.pal@mail.ru)

Кривец Тамара Павловна, к.э.н. доцент, Кафедра бухгалтерского учета, анализа и аудита Дальневосточного федерального университета, г. Владивосток

ПОСТУПИЛО В РЕДАКЦИЮ: 01.07.2014 / ОПУБЛИКОВАНО: 26.12.2014

ОткРЫтЫЙ дОстУп:

http://journals.creativeconomy.ru/index.php/epp/article/view/301/

(с) Палкина Ю.А., Кривец Т.П. / Публикация: ООО Издательство "Креативная экономика"

Статья распространяется по лицензии Creative Commons CC BY-NC-ND (http://creativecommons.org/licenses/by-nc-nd/3.0/)

ЯЗЫК ПУБЛИКАЦИИ: русский 
В современной экономике предприятие живет в стремительном ритме, постоянно подстраиваясь на изменения ориентации экономики, спроса и предложения, законодательства и прочих условиях хозяйственно-экономической деятельности. В таком ритме очень важна быстрота реакции директора и бухгалтера организации на внешние изменения.

Бухгалтер - это очень важная персона на предприятии, потому что он обладает информацией обо всех хозяйственных действиях, выявляет результаты деятельности, наиболее прибыльные и убыточные статьи и при правильном использовании информации законными путями минимизирует налоги. Именно от грамотной работы бухгалтера зависит величина прибыли предприятия и сумма перечислений в бюджет, а также его стабильность и рентабельность.

Тем не менее, работа бухгалтера является очень ответственной и требует высокой профессиональности, усидчивости, выдержки и интеллектуальной подготовленности. Ведь по степени ответственности работа бухгалтера может сравниться только с обязанностями генерального директора организации. Но нередко бухгалтеры халатно относятся к возложенным на них обязанностям, пользуются служебным положением и ведут так называемую «черную бухгалтерию».

Данная тема является актуальной потому, что, принимая на работу бухгалтера, а особенно главного бухгалтера, предприятие несет некоторые риски, связанные с тем, что принимаемый человек может оказаться мошенником. Генеральный директор предприятия должен знать, в каких областях ему следует проявить осторожность и наивысшую наблюдательность, чтобы не допустить махинаций бухгалтера, а бухгалтер, в свою очередь, должен понимать, что его махинации несут за собой наказание - и порой довольно суровое - и заранее знать последствия своих действий. Так как в условиях нестабильной российской экономики при выявлении каких-либо нарушений в организации в первую очередь к ответственности призывается именно бухгалтер.

Для бухгалтера, как и для любого другого работника, существует четыре вида ответственности: дисциплинарная, материальная, административная и уголовная (ст. 192 ТК). От дисциплинарных проступков не застрахован никто, к тому же большую роль здесь играет человеческий фактор, а вот более серьезные наказания бухгалтер может получить по умышленно совершенным махинациям. Почему же у 
бухгалтера иногда возникает желание совершить такое преступление? Приведем некоторые причины бухгалтерского мошенничества:

- неудовлетворенность уровнем своего дохода;

- возникновение сложных жизненных обстоятельств;

- желание воспользоваться высоким служебным положением ради собственной выгоды;

- стремление угодить руководителю и минимизировать налоги;

- ошибочное мнение о том, что мошеннические действия невозможно проконтролировать и выявить.

Согласно информации правоохранительных органов, бухгалтеры чаще всего фигурируют в делах о мошенничестве, растрате, незаконном присвоении денег, сокрытии некоторых статей дохода с целью уменьшения прибыли и фиктивном или преднамеренном банкротстве.

Итак, субъектом преступления в данной сфере экономической деятельности является бухгалтер, субъективной стороной - желание воспользоваться служебным положением и данной властью, а объектом финансовые активы организации и объективной стороной - махинации в сфере денежного обращения предприятия.

Некоторые преступления могут быль совершены только на крупных предприятиях, а некоторые только на мелких, но, тем не менее, все бухгалтерские махинации могут нанести непоправимый урон компании в целом. Рассмотрим самые распространенные бухгалтерские преступления, которые, по мнению многих юристов, можно классифицировать следующим образом:

\section{- «Зарплатное баловство»}

Бухгалтер пользуется тем, что денежные потоки проходят непосредственно через него и какие-либо другие лица задействуются редко. И, несмотря на то, что большинство перечислений денежный средств сейчас проходит не наличными, а через систему «клиент-банк», бухгалтер все равно фальсифицирует документы.

Например, при подготовке реестра зарплат бухгалтер может завышать суммы окладов и излишки перечислять себе на счет. За совершение подобной махинации в крупном размере бухгалтера могут приговорить к условному лишению свободы или штрафу (ч. 3, 4 ст. 159 УК РФ).

\section{- «Мертвые души» \\ Это мошенничество является разновидностью «зарплатного} баловства», но влечет за собой более суровое наказание. 
В этом случае бухгалтер создает несуществующих работников, которым начисляется и платится зарплата, после того денежные средства, начисленные так называемым «призракам», переходят в карман бухгалтера. За такие махинации бухгалтер может получить наказание от штрафа до лишения свободы (ч. 3 ст. 160 УК РФ - до 6 лет лишения свободы).

Примером такой махинации может послужить случай в головной организации ООО «Астраханьгазпром». Бухгалтер включала в реестр зарплат фамилии умерших пенсионеров предприятия и их родственников, в результате чего присвоила себе 1 млн рублей. За свою мошенническую деятельность сотрудница была приговорена к штрафу в 50 тыс. руб. и лишению свободы условно.

\section{- $\quad$ Прятки с налоговыми органами}

Наверное, наиболее распространенным видом мошенничества бухгалтера является сокрытие прибыли с целью уменьшения налогов. Около 30\% компаний врут налоговым и скрывают свою реальную прибыль, и число таких преступлений постоянно растет.

Иногда случается так, что директор предприятия заинтересован в том, чтобы фирма платила меньше налогов. Он отдает приказ главному бухгалтеру (чаще в устной форме), используя «серые» махинации, не платить часть налогов или скрывать прибыль от какой-либо деятельности компании. Чаще всего бухгалтер соглашается пойти на подобную махинацию, потому что боится потерять работу и считает, что ответственность все равно ляжет на руководителя. И на самом деле ответственность за соблюдение бухгалтерского учета несет руководитель, а бухгалтер только за правильное ведение бухгалтерского учета [8]. Но чаще всего такие махинации совершаются по обоюдному согласию и к ответственности привлекаются как бухгалтер, так и руководитель [2].

\section{- Хищения с отмыванием}

Хищение с отмыванием - это незаконный перевод денежных средств на свой счет и использование их в легальном денежном обороте (например, на уплату кредита, совершения покупок, передачи взаймы).

Такие махинации чаще всего выступают в виде вывода денег по фиктивным договорам. То есть, пользуясь своим правом подписи, бухгалтер составляет фиктивный договор и отправляет денежные средства на счет несуществующий фирмы, а потом пользуется этими средствами в своих целях. За подобные хищения наказание по ч. 1 и 2 
ст. 174.1 УК РФ определяется в зависимости от размеров легализованного: штраф 100-500 тыс. руб. или лишение свободы до 5 лет $[3]$.

\section{- «Игра с цифрами»}

Нередко для присвоения и обналичивания денег бухгалтер перечисляет денежные средства по фиктивным договорам на счет фирм«однодневок». В такой ситуации бухгалтер будет отвечать как за мошенничество, так и за подделку документов.

Например, главный бухгалтер $3 \mathrm{AO}$ «База технического обслуживания флота» была поймана за подделку платежек, с помощью которых она переводила деньги на счета фиктивных организаций. Суд приговорил сотрудницу к двум годам лишения свободы и штрафу в размере 300 тыс. руб.

Также бухгалтер может быть наказан за дачу взяток в случае, например, когда правоохранительными органами были выявлены крупные нарушения, а бухгалтер пытался их скрыть. Наказание за такие действие - штраф или лишение свободы на срок до 8 лет (ст. 291 УК РФ).

Довольно суровое наказание ждет бухгалтера за сокрытие сведений об имуществе организации с целью предотвращения банкротства. Кстати, в этом году Минфин подготовил проект с изменениями в Уголовном кодексе в соответствии с которым бухгалтеров, сфальсифицировавших отчетность, чтобы скрыть признаки банкротства, будут наказывать штрафом, принудительными работами и лишением свободы на срок до 4 лет [5].

Все хищения и махинации бухгалтеров можно выявить, если знать, в каких областях нужно проявить осторожность и предусмотрительность. Руководителю не помешало бы проводить фактический осмотр наличных денежный средств и сверять их с суммами, отраженными на бумаге, также исследовать результаты финансового анализа для того, чтобы выявить наличие хищений в собственной организации. Для того чтобы проверить законность и необходимость вызывающих подозрение финансовых операций, можно исследовать первичные бухгалтерские документы, а также оформление этих самых документов. При приеме на работу бухгалтера и главного бухгалтера целесообразно будет узнать о его прежних заслугах, наличии судимости, постановлении на учет в психоневрологических и наркологических диспансерах. Также необходимо заключить договоры о 
полной материальной ответственности с кассирами, бухгалтерами, главными бухгалтерами и не реже одного раза в месяц проводить доскональную инвентаризацию денежных средств. При этом лучше привлекать специалистов извне. Также довольно эффективно будет принять меры стимулирования бухгалтеров, чтобы они стремились выполнять свою работу честно и не думали о махинациях, не давать сотрудникам забывать о мерах наказания, которые их ждут при совершении незаконных поступков [6]. Но самым действенным способом борьбы с преступлениями бухгалтера являются регулярные независимые аудиторские проверки или передача ведения бухгалтерского учета аутсорсинговой компании. Такие действия, к сожалению, не смогут полностью застраховать фирму от мошенничества бухгалтеров, но значительно снизят их вероятность.

Таким образом, подводя итог проведенному исследованию, следует заметить, что преступление бухгалтера на предприятии является одним из самых распространенных видов экономических преступлений. Несмотря на суровые наказания, до сих пор нет четко установленных методов борьбы с мошенничеством бухгалтера на предприятии, но реализация предложенных нами мероприятий позволит уменьшить риск возникновения этого вида преступлений на предприятии.

\section{Источники:}

1. Голова И. Игра с цифрами // Российская бизнес газета. - 2013. - № 908 (30)

2. Камалова Е. За что могут наказать главного бухгалтера? // Московский бухгалтер. 2007. - № 2.

3. Карамазова T. Неналоговые преступления бухгалтеров // Экономические преступления. - 2009. - № 1.

4. Преступления бухгалтеров // Сайт «dbanking»

5. Рамазанов И. В чем помимо неуплаты налогов могут обвинить бухгалтера? // Экономические преступления». - 2009. - № 11.

6. Савин Д. Мошенничество бухгалтеров: как выявить и предотвратить // Сайт «Бухгалтерия.ru»

7. Трудовой кодекс Российской Федерации от 30.12.2001 № 197-Ф3

8. Федеральный закон от 06.12.2011 № 402-Ф3 «О бухгалтерском учете» (ред. от 04.11.2014) 
Palkina Yu. A., Student , Far Eastern Federal University

Krivets T.P., Candidate of Science, Economics, Far Eastern Federal University

\section{Crimes in the economic sphere: the responsibility of an accountant}

\section{ABSTRACT:}

The article reveals the features of economic crimes for example crimes accountant at the company. Author highlights the major reasons accounting offenses considered major classification of crimes and punishment designated for their commission based on the articles of the Tax Code. Furthermore the author proposed ways to prevent crime in the company accountant.

KEYWORDS: accountant, risks, responsibilities, subject and object of the crime, fraud, punishment 
